\title{
Orális antikoagulánssal már kezelt pitvarfibrilláló betegek egyéves terápiahúsége
}

\author{
Simonyi Gábor dr. ${ }^{1}$. Ferenci Tamás dr. ${ }^{2}$ \\ Finta Ervin dr. ${ }^{3}$ - Gasparics Roland $d .^{1}{ }^{-}$Medvegy Mihály dr. ${ }^{4}$ \\ ${ }^{1}$ Szent Imre Egyetemi Oktatókórház, Anyagcsere Központ, Budapest \\ ${ }^{2}$ Óbudai Egyetem, Neumann János Informatikai Kar, Élettani Szabályozások Csoport, Budapest \\ ${ }^{3}$ Szent Imre Egyetemi Oktatókórház, Kiemelt Hotelszolgálat I. Budapest \\ ${ }^{4}$ Pest Megyei Flór Ferenc Kórház, III. Belgyógyászat-Kardiológiai Osztály, Kistarcsa
}

\begin{abstract}
Bevezetés: A nonvalvularis pitvarfibrilláció ( $\mathrm{PF}$ ) orális antikoagulánssal (OAK) történő kezelésekor a terápiahűség igen jelentős tényező a stroke prevenciójában.

Célkitüzések: A szerzők célja a már OAK-terápiában részesülő PF-ban szenvedő betegeknél a K-vitamin-antagonista (KVA) és a direkt orális antikoagulánsok (DOAK) egyéves perzisztenciájának vizsgálata.

Módszer: A Nemzeti Egészségbiztosítási Alapkezelő adatbázisából a vényforgalmi adatokra támaszkodva pitvarfibrilláció indikációjában, 2015 második félévében valamely orális antikoaguláns $(\mathrm{OAK}=\mathrm{KVA} / \mathrm{DOAK})$ receptjét kiváltó olyan betegeket választottak ki, akiknek a vizsgálati időszakot megelőzően - a vizsgálati időszakban történt kiváltási dátumhoz képest - 12 hónappal korábban volt (DOAK/KVA összes) vénykiváltásuk. A perzisztencia modellezésére a túlélés-analízis klasszikus eszköztárát alkalmazták, ahol a „túlélési” idő a gyógyszer szedésének abbahagyásáig eltelt idő volt, 60 napos 'grace' periódussal.

Eredmények: A bevonási kritériumoknak 196016 beteg felelt meg. A betegek közül 181810 szedett KVA-t, míg 14206 beteg kapott DOAK-ot. A KVA-k egyéves perzisztenciája 52,9\%, a DOAK-ot szedőké 66,8\% volt. A DOAKterápián belül a rivaroxaban egyéves perzisztenciája $67,5 \%$, az apixabané $63,6 \%$, a dabigatrané $63,4 \%$ volt. A 360 napra korlátozott átlagos gyógyszerszedési idő 311 nap volt a rivaroxaban, 308 nap az apixaban, 303 nap a dabigatran, míg 284 nap a KVA-k esetén. A gyógyszerelhagyás kockázatának pillanatnyi rátája az apixaban esetén 14\%-kal $(\mathrm{HR}=1,14$ [95\% CI 1,05-1,24]), p = 0,0015), a dabigatrannál 15\%-kal (HR = 1,15 [95\% CI 1,08-1,23], p = 0,003), a KVA-t szedőknél 62\%-kal (HR = 1,62 [95\% CI 1,56-1,69], p<0,0001) volt magasabb a rivaroxabanhoz képest. Következtetés: A szerzők igazolták, hogy PF-ban a KVA-terápiához képest a DOAK-ok egyéves perzisztenciája szignifikánsan magasabb volt. A DOAK-ok közül a rivaroxaban egyéves perzisztenciája előnyösebbnek bizonyult az apixabanhoz és a dabigatranhoz képest.
\end{abstract}

Orv Hetil. 2019; 160(13): 509-515.

Kulcsszavak: pitvarfibilláció, K-vitamin-antagonisták, adherencia, új orális antikoagulánsok

\section{One-year persistence of patients already treated with oral anticoagulants for atrial fibrillation}

Introduction: In the treatment of non-valvular atrial fibrillation (AF) with oral anticoagulants (OAC), medical adherence is a relevant factor for stroke prevention.

Aim: To evaluate the one-year persistence of vitamin K antagonists (VKA) and direct oral anticoagulants (DOAC) in patients suffering from AF and already treated with OACs.

Method: Information from the National Health Insurance Fund of Hungary prescriptions database on pharmacy claims between June 1, 2015 and December 31, 2015 was analysed. Authors identified patients who filled prescriptions for OACs (VKAs or DOACs) prescribed for AF who have already received OACs therapy during one year before. Apparatus of survival analysis was used, where 'survival' was the time to abandon the medication.

Results: 196016 patients met the inclusion criteria. 181810 patients received VKA and 14206 patients were treated with DOACs. The one-year persistence rate in patients taking VKA was $52.9 \%$ whereas it was $66.8 \%$ in those on the DOACs. The persistence rates after 360 days were $67.5 \%$ for rivaroxaban, $63.6 \%$ for apixaban and $63.4 \%$ for dabi- 
gatran. The mean duration of persistence was 311 days for rivaroxaban, 308 days for apixaban and 284 days for dabigatran. The actual rate of discontinuation was $14 \%(\mathrm{HR}=1.14$ [95\% CI 1.05-1.24]), $\mathrm{p}=0.0015)$ for apixaban, $15 \%(\mathrm{HR}=1.15$ [95\% CI 1.08-1.23], $\mathrm{p}=0.003)$ for dabigatran and 62\% $(\mathrm{HR}=1.62$ [95\% CI $1.56-1.69], \mathrm{p}<0.0001)$ for VKA compared to rivaroxaban (reference).

Conclusions: The authors have confirmed that the one-year persistence of DOAKs was significantly higher compared to KVA therapy in AF. The one-year persistence of rivaroxaban was more favoured than apixaban and dabigatran.

Keywords: atrial fibrillation, vitamin $\mathrm{K}$ antagonists, adherence, novel oral anticoagulants

Simonyi G, Ferenci T, Finta E, Gasparics R, Medvegy M. [One-year persistence of patients already treated with oral anticoagulants for atrial fibrillation]. Orv Hetil. 2019; 160(13): 509-515.

(Beérkezett: 2018. november 1.; elfogadva: 2018. november 14.)

\begin{abstract}
Rövidítések
$\mathrm{BNO}=$ betegségek nemzetközi osztályozása; $\mathrm{CI}=$ konfidenciaintervallum; $\mathrm{DOAK}=($ direct oral anticoagulant $)$ direkt orális antikoaguláns; ESC = (European Society of Cardiology $)$ Európai Kardiológiai Társaság; HR = (hazard ratio) kockázati arány; INR = (international normalized ratio) nemzetközi normalizált ráta; $\mathrm{KVA}=$ (vitamin $\mathrm{K}$ antagonists) $\mathrm{K}$-vitamin-antagonista; NEAK = Nemzeti Egészségbiztosítási Alapkezelő; $\mathrm{OAK}=($ oral anticoagulant $)$ orális antikoaguláns; $\mathrm{OEP}=\mathrm{Or}-$ szágos Egészségbiztosítási Pénztár; $\mathrm{PF}$ = pitvarfibrilláció; $\mathrm{SE}=$ (standard error) standard hiba
\end{abstract}

A pitvarfibrilláció ( $\mathrm{PF}$ ) a leggyakoribb ritmuszavar, amely egyben a stroke kifejezett kockázati tényezője. PF fennállása esetén az ischaemiás stroke kockázata jelentősen, mintegy 4-5-szörösére nő [1, 2]. A tünetekkel kísért PF rontja az életminőséget, limitálhatja a fizikai teljesítőképességet, csökkenti a szív ejekciós funkcióját. Mindezek mellett PF esetén gyakoribb a hospitalizáció, emelkednek az egészségügyi kiadások, de talán a legfontosabb, hogy fokozódik a mortalitás is [3]. Az OEP adatbázisára alapozó hazai felmérés szerint a pitvarfibrilláció-prevalencia 2,37-2,67\%-ra tehető. Az adatok matematikai modellezésével a PF teljes hazai gyakoriságát 2,95\%-nak találták, ami 296493 pitvarfibrilláló beteget jelentett [4].

A nonvalvularis PF-ban szenvedők orálisantikoaguláns (OAK)-terápiájára sokáig csak a K-vitamin-antagonisták (KVA) voltak elérhetők, ugyanakkor az elmúlt években a direkt orális antikoagulánsok (DOAK) újabb és újabb képviselői kerültek forgalomba hazánkban is [5].

A KVA-terápia során számos nehézséggel kerülünk szembe (például rendszeres INR-ellenőrzés és a dózis gyakori változtatása), miközben hatékonysága és biztonságossága alapvetően az INR-szinttől függ [6]. A DOAK-terápia esetében hasonló kihívással nem szembesülünk, mivel hatásuk monitorozása nem szükséges, a dózis változtatására is csak bizonyos esetekben (például időskor, beszúkült vesefunkció) kényszerülünk.
Minden OAK-terápia során - hatásosság és biztonságossági szempontból - elengedhetetlen a gyógyszerszedési utasítások pontos betartása. A rossz betegadherencia esetében nő a stroke/halálozás kockázata [7].

\section{Célkitüzések}

Vizsgálatunkban a hazai OAK- (DOAK- és KVA-) terápia egyéves terápiahüségének felmérését terveztük, korábban már OAK-kezelésben részesülő pitvarfibrilláló betegeknél. A perzisztenciaadatok mellett az egyes hatóanyagokra jellemző más paramétereket (például átlagos gyógyszerszedési idő, az egyes hatóanyagok elhagyásának rátája) is vizsgáltunk.

\section{Betegek és módszer}

Retrospektív vizsgálatunkban a Nemzeti Egészségbiztosítási Alapkezelő (NEAK) adatbázisából azokat a betegeket választottuk ki, akik 2015 második félévében (a június 1-jétől december 31-ig terjedő időszakban) orálisantikoaguláns- (bármelyik KVA- vagy bármelyik DOAK-) terápiában részesültek pitvarfibrilláció $(\mathrm{BNO}=$ Il0H0) indikációjában. E betegek közül azokat választottuk ki, akik a fent említett bevonási időszakot megelőző 12 hónapban már legalább egy DOAK- vagy KVAreceptet kiváltottak. A KVA-terápiában részesülő betegek receptkiváltásait nem bontottuk le hatóanyagokra (warfarin vagy acenokumarol). Ezzel szemben a DOAK-terápiás csoportot a vizsgálati időszakban forgalomban lévő hatóanyagok szintjén is vizsgáltuk.

A receptkiváltásokat minden betegnél 14 hónapig, legkésőbb 2017. február 28-ig követtük. A perzisztenciaelemzésből kizártuk a követési időszak alatt elhalálozott betegeket. Hatvannapos gyógyszerkihagyást tolerálva ('grace' periódus) vizsgáltuk, hogy az előbbi kritériumoknak megfelelt és követett betegek mekkora hányada maradt az adott OAK-terápián. A NEAK adatbázisában a receptkiváltási adatok 30 napos időközönként voltak elérhetők. 


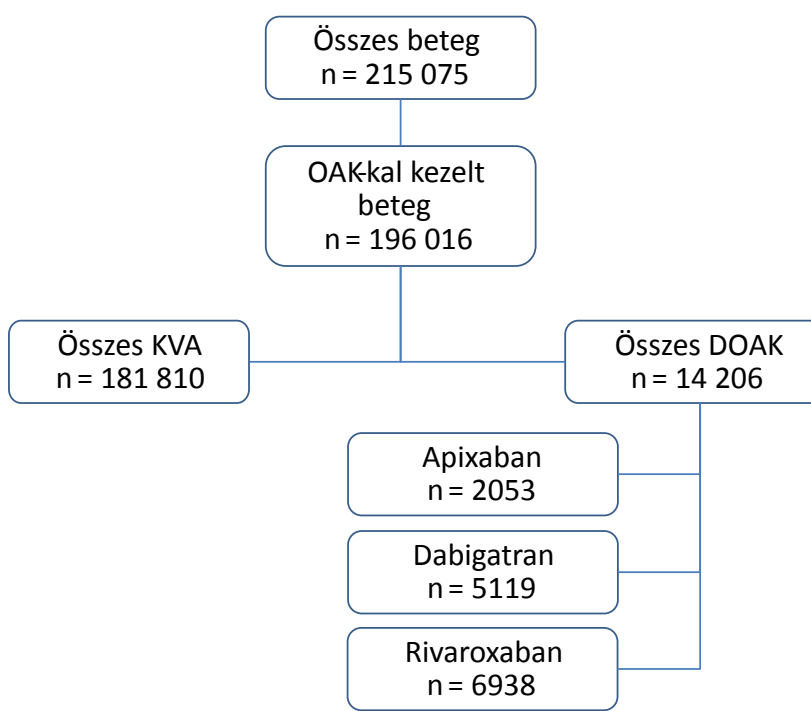

1. ábra

A korábban már OAK-terápiában részesült PF-betegek megoszlása a hatóanyagcsoportok és a DOAK-hatóanyagok szerint

DOAK $=$ direkt orális antikoaguláns; $\mathrm{OAK}=$ orális antikoagu láns; $\mathrm{PF}=$ pitvarfibrilláció

Az OAK-terápia perzisztenciamodellezésére a túlélésanalízis klasszikus eszköztárát alkalmaztuk úgy, hogy a „túlélési idő” a gyógyszer szedésének kezdetétől egészen az annak elhagyásáig eltelt idő volt. Perzisztenciavizsgá- latunkban az egyetlen magyarázó változó tényező a gyógyszer típusa (KVA [összes] vagy DOAK [összes], illetve a DOAK-hatóanyagok szerint) volt. Mivel a perzisztenciaadatok 30 napos frekvenciával voltak elérhetők, diszkrét idejû túlélést becsültünk, és ábrázoltuk az idő függvényében. A modellezéshez komplementer loglog link függvényt használó általánosított lineáris modellt becsültünk, amely a jól ismert (folytonos idejü) túlélés-elemzés bevált diszkrét idejü megfelelője $[8,9]$. A gyógyszerek között a hazárd proporcionalitását úgy ellenőriztük, hogy hozzáadtuk a modellhez a gyógyszer és az eltelt idő interakcióját, majd összehasonlítottuk ennek a - szaturált - modellnek az illeszkedését az eredeti modellével. Amennyiben a nemproporcionalitás nem volt jelentős, úgy meghatároztuk a gyógyszerszedés abbahagyásának hazárdját (HR) is, a referenciaként használt rivaroxabanhoz viszonyítva. Mindezek mellett kiszámoltuk a KVA-terápia, illetve az egyes DOAK-hatóanyagoknak a 12 hónapra korlátozott átlagos túlélési (szedési) idejét is [10].

\section{Eredmények}

A NEAK adatbázisában 215075 olyan beteget találtunk, akik a 2015. év második felében valamilyen OAK-terápiában részesültek. E betegek közül mindösszesen 196016 felelt meg a fent részletezett bevonási kritériumoknak.

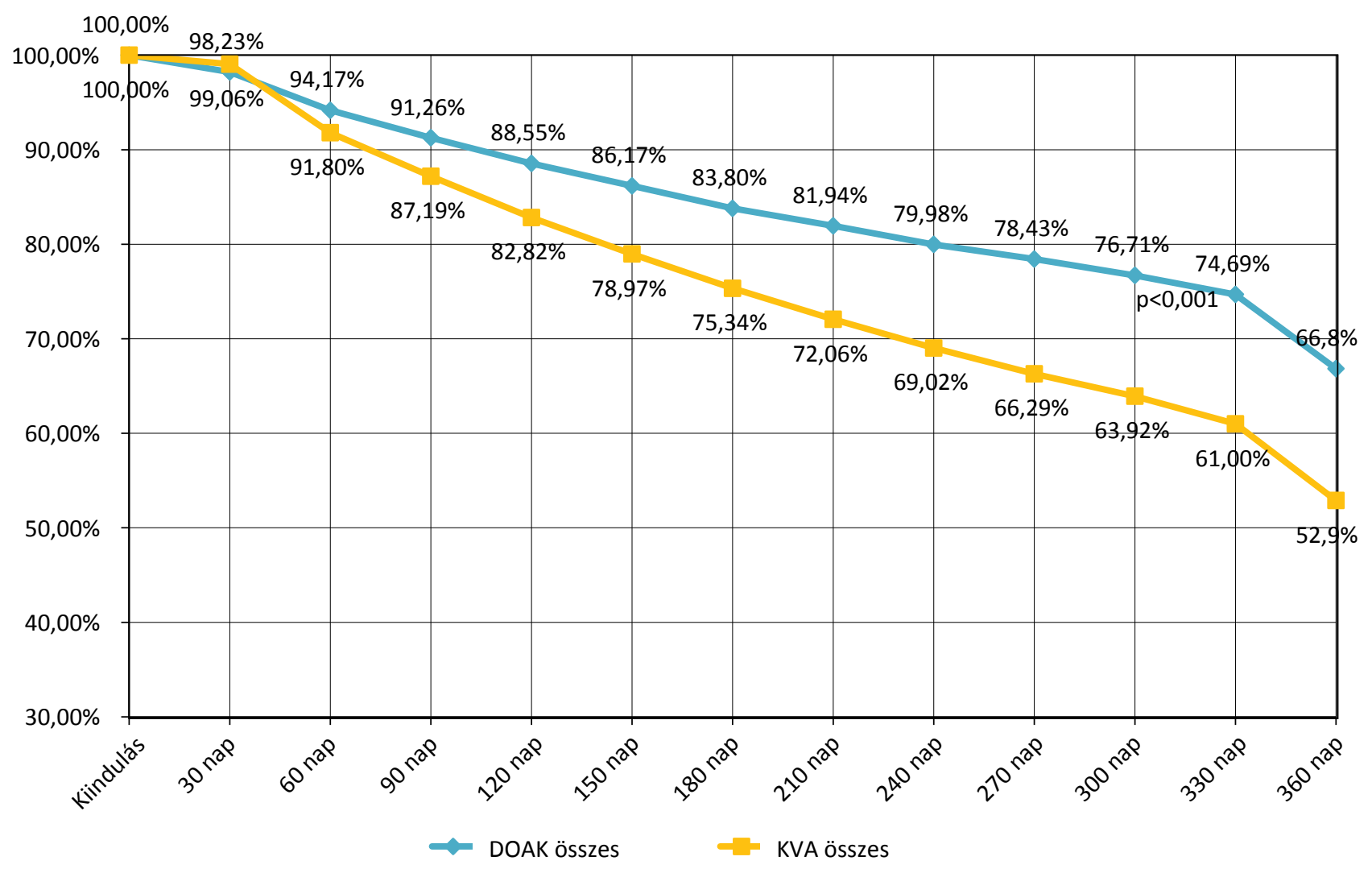

2. ábra

\footnotetext{
Az egyéves KVA- (összes) és DOAK- (összes) perzisztencia

DOAK $=$ direkt orális antikoaguláns; $\mathrm{KVA}=\mathrm{K}$-vitamin-antagonista
} 


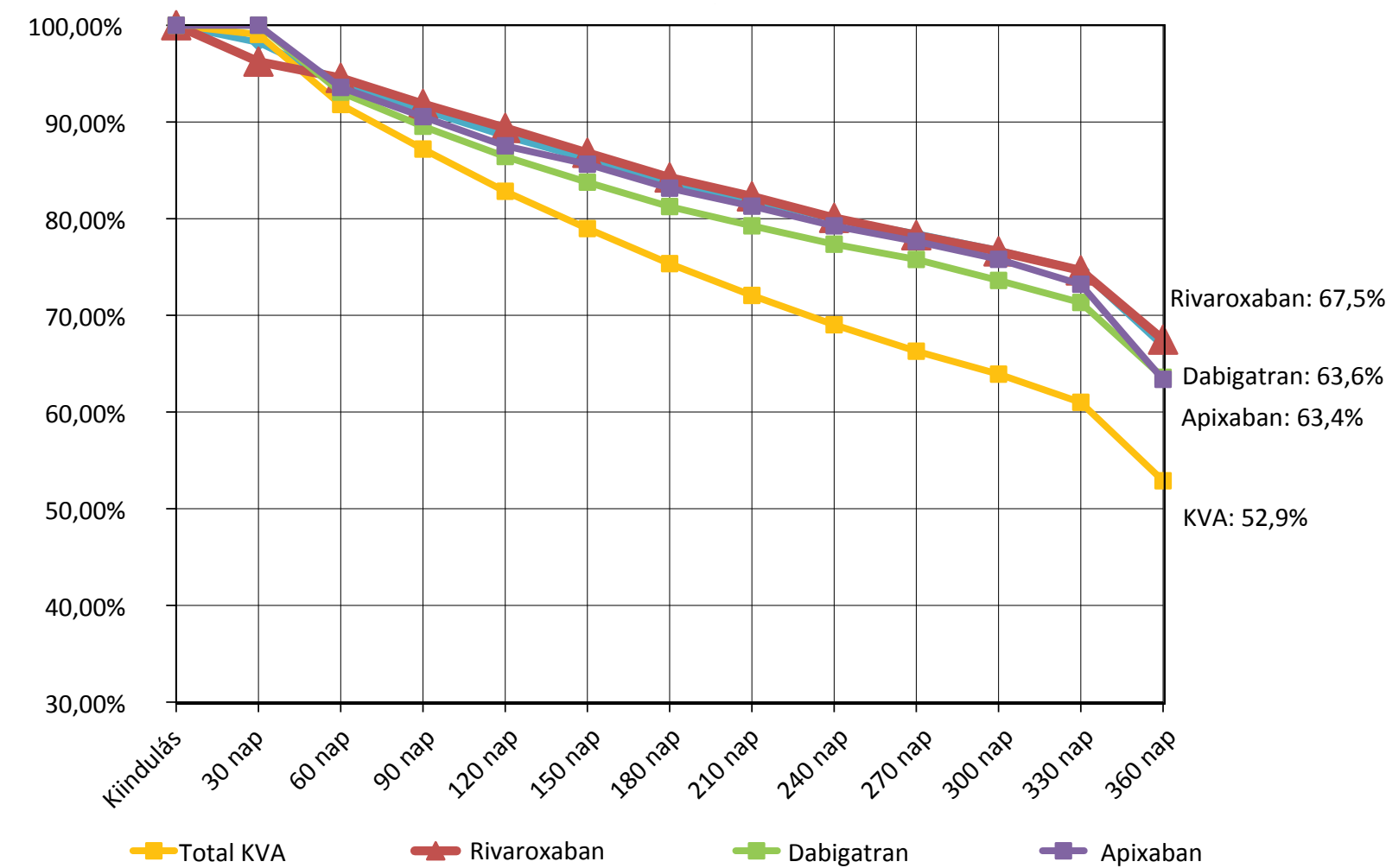

3. ábra $\mid$ Az egyéves KVA- (összes) és DOAK- (hatóanyagok szerinti) perzisztencia

DOAK = direkt orális antikoaguláns; KVA = K-vitamin-antagonista

A vizsgálatba bevontak közül 181810 szedett valamely KVA-hatóanyagot (KVA összes), míg 14206 beteg részesült valamelyik DOAK- (DOAK összes) terápiában. A DOAK-ot szedők közül 2053 beteg kapott apixaban-, 5119 dabigatran-, míg 6938 rivaroxabanterápiát (1. ábra). Az edoxaban csak 2016. július 1 -jével vált elérhetővé hazánkban, ezért elemzésünkben ilyen betegek nem szerepelhettek.

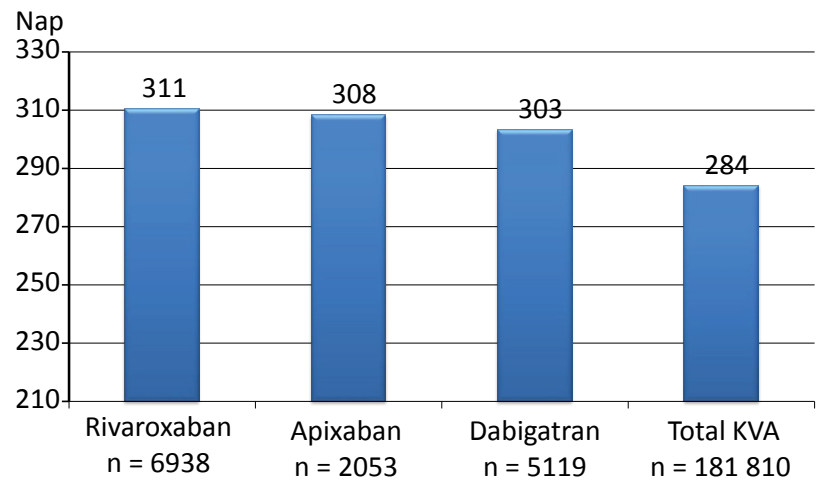

4. ábra (összes) és az egyes DOAK-hatóanyagok esetében DOAK = direkt orális antikoaguláns; KVA = K-vitamin-antago-
A KVA-k egyéves perzisztenciája 52,9\%, a DOAK-ot szedőké $66,8 \%$ volt (2. ábra), ami 14 százalékpontos különbséget jelentett $(\mathrm{p}<0,001)$. A DOAK-terápián belül a rivaroxaban egyéves perzisztenciája $67,5 \%$, az apixabané $63,6 \%$, a dabigatrané $63,4 \%$ volt (3. ábra). A KVA-terápiához képest az apixaban és a dabigatran szedése mintegy 10 százalékpontos előnyt nyújtott, ezzel szemben a rivaroxaban majdnem 15 százalékponttal volt előnyösebb. A 360 napra korlátozott átlagos gyógyszerszedési idő 311 (SE: 1,17) nap volt a rivaroxaban, 308 (SE: $2,16)$ nap az apixaban, 303 nap (SE: 1,42) a dabigatran, míg 284 (SE: 0,31) nap a KVA-k esetén (4. ábra).

A diszkrét túlélés-elemzési modell eredményei szerint a nemproporcionalitás mindössze $0,2 \%$-os lett (ennyi a proporcionális és a szaturált modell devianciái közti különbség, relatíve a proporcinális nulldevianciájához képest), ezért alkalmazhattuk a proporcionális modellt és ennek révén a HR-t. E szerint a gyógyszerelhagyás kockázatának pillanatnyi rátája az apixaban esetén $14 \%$-kal $(\mathrm{HR}=1,14[95 \%$ CI $1,05-1,24]), \mathrm{p}=0,0015)$, a dabigatrannál 15\%-kal (HR = 1,15 [95\% CI 1,08-1,23], $\mathrm{p}=0,003)$, a KVA-t szedóknél $62 \%$-kal $(\mathrm{HR}=1,62$ [95\% CI $1,56-1,69], \mathrm{p}<0,0001)$ volt magasabb a rivaroxabanhoz képest (5. ábra). Mindez azt jelentette, hogy a rivaroxabanhoz képest a többi DOAK-, illetve a KVAterápia elhagyásának szignifikánsan kifejezettebb volt a kockázata. 


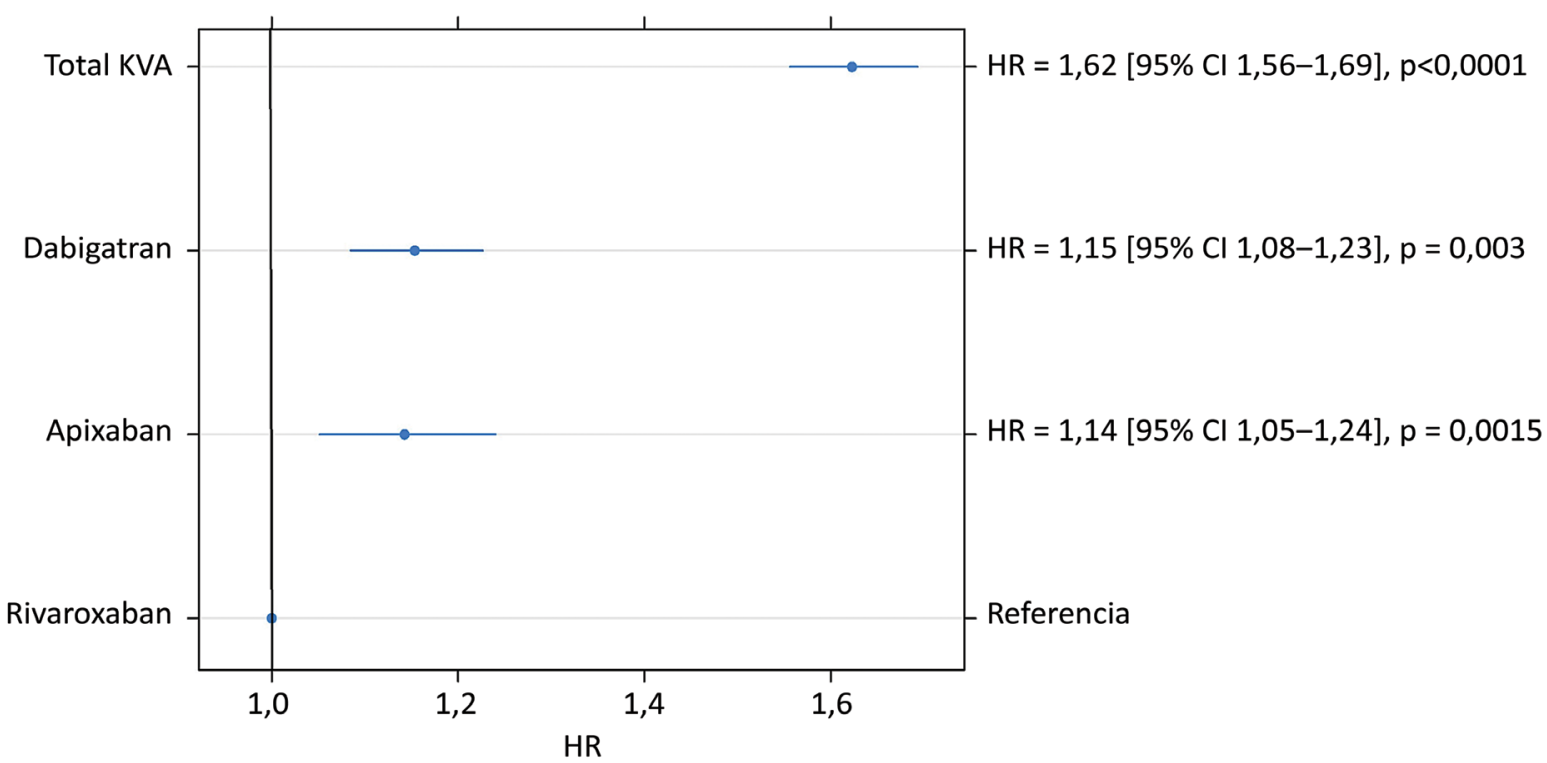

5. ábra A gyógyszerelhagyás kockázatának pillanatnyi rátája (HR) a rivaroxabanhoz (referencia) képest
HR = kockázati arány

\section{Megbeszélés}

A jó terápiahûség minden krónikus betegségben alapvetô a kezelt betegség prognózisának javítása, illetve a szövődmények elkerülése érdekében [11]. Vizsgálatunk hazai vonatkozásban egyedülálló, mivel hasonló „realworld" adatok nem álltak még rendelkezésünkre az OAK-terápia adherenciájával összefüggésben olyan betegeknél, akik korábban már valamely OAK-terápiában részesültek. A mintegy 200000 PF-beteg adatainak értékelésével igazoltuk, hogy e betegcsoport esetében a DOAK-terápia előnyösebb a KVA-kezelésnél. A DOAKhatóanyagok közül a rivaroxaban szignifikánsan magasabb egyéves terápiahúséggel rendelkezett $(67,5 \%)$ az apiaxabanhoz $(63,6 \%)$, a dabigatranhoz $(63,4 \%)$ vagy a KVA-terápiához $(52,9 \%)$ képest.

Hazai eredmények korábbról csak a KVA perzisztenciájának vonatkozásában érhetők el [12]. Korábbi vizsgálatunkban az újonnan KVA-terápiát kezdők egyéves perzisztenciáját vizsgáltuk az Országos Egészségbiztosítási Pénztár adatainak feldolgozásával. E vizsgálatunkban a KVA-terápia egyéves perzisztenciáját 30\%-nak találtuk, ami lényegesen alacsonyabbnak bizonyult a jelen tanulmányunkban tapasztalt 52,9\%-hoz képest. A KVA-terápia egyéves perzisztenciájának jelentôs különbsége mögött több tényező állhat. A különbség egyik oka az lehet, hogy jelen vizsgálatunkban a már korábban OAK-terápián lévők terápiahűségét vizsgáltuk, ugyanakkor régóta ismert, hogy az új betegek terápiahúsége alacsonyabb [13], és ez a hatás okozhatta a két vizsgálat KVA-perzisztencia-különbségét. A különbség másik eleme az lehet, hogy a két vizsgálat között eltelt mintegy 5 év alatt - a DOAK-ok megjelenésével - a PF kezelésére sokkal nagyobb figyelem hárult, a korábbiakhoz képest.
A KVA-terápia alacsonyabb terápiahüsége - a DOAKkezeléssel szemben - viszont egyáltalán nem meglepő eredmény. Jól ismert, hogy PF-ban a KVA-val végzett antikoagulálást számos tényező befolyásolhatja. Ennek egyik eleme az INR-érték szoros monitorozása, amely sokszor nem biztosítható (például otthon fekvő beteg, a vérvételi helytől távol élő beteg), illetve ha a beteg nem jelenik meg a kontrollvizsgálatokon. Probléma az is, hogy a stroke szempontjából nagy kockázatú betegeknek csak a 40-70\%-a részesül KVA-terápiában. A KVAterápia során az INR terápiás tartományban tartása sem optimális, mivel a betegek mintegy kétharmada lehet csak megfelelően antikoagulálva. A magasabb INR-érték a vérzéses szövődmények kockázatát emeli, míg a szubterápiás INR-értéken lévők esetében a stroke kialakulásának lesz nagyobb a kockázata $[14,15]$.

A KVA-terápiával szemben a DOAK-kezelés magasabb terápiahúségének hátterében többek között a fix adagok, az étel- és az alkoholinterakciók hiánya, a szignifikánsan kevesebb gyógyszer-interakció, illetve a hasonló vagy kifejezettebb hatásosság és biztonságosság állhat. Mindezeken túlmenően a dózis-hatás (INR) rendszeres ellenőrzésének elmaradása is növeli a betegadherenciát, különösen olyan helyeken, ahol ez nehezen oldható meg [14].

A nemzetközi irodalomban számos „real-world” vizsgálatban értékelték a különböző DOAK-hatóanyagok adherenciáját. A mi vizsgálatunkhoz hasonlóan ezekben is jellemzően egy-egy egészségbiztosítási adatbázis vagy regiszter alapján tanulmányozták a terápiahűségét, de kisebb esetszámmal. E vizsgálatokban az apixabanadherenciát 61,9-93,5\%-nak, a dabigatranét 74-99,7\%nak, míg a rivaroxabanét 78,8-82,5\%-nak találták [14]. 
Egy vizsgálatban, ahol az újonnan OAK-terápiában részesültek egyéves perzisztenciáját tanulmányozták, a rivaroxaban egyéves perzisztenciája $53,1 \%$, míg a dabigatrané $47,3 \%$ volt; az apixabanról ebben a vizsgálatban nem közöltek adatokat [16]. E vizsgálati adatok nagyfokú szórásának hátterében a nem egységes metodika, az esetenként kis elemszámú regiszterek adatainak heterogenitása állhat.

$\mathrm{Az}$ adherenciaadatok ennek ellenére egyfelé mutatnak, azaz még a DOAK-terápia során sem tökéletes a betegek terápiahűsége, mivel az adherencia sokszor $80 \%$ alatti, miközben a stroke-kal szembeni teljes védelemhez 100\%-os adherenciára lenne szükségünk. A 100\% alatti adherencia a stroke-prevencióban azt jelenti, hogy e betegeknél sok-sok nap vagy akár hét is eltelhet a megfelelő védelem nélkül, ami egyértelmúen fokozza a stroke-kockázatot, fóleg a magasabb stroke-kockázattal rendelkező betegeknél.

Az egyes DOAK-hatóanyagok közötti eltérő terápiahúség okai - más krónikus terápiákhoz hasonlóan - igen szerteágazóak lehetnek, aminek hátterében részben a napi adagok száma, a mellékhatások gyakorisága, a hatásosság és a biztonságosság állhat.

A DOAK-ok bevezetésével lényegesen egyszerüsödött PF-betegeink antikoagulánsterápiája, amelyet a KVA-val szemben magasabb terápiahűség is jellemez. A hazai és a nemzetközi adatok fényében megállapíthatjuk, hogy még a DOAK-terápia során is javítanunk kell betegeink terápiahüségén. Ennek eleme lehet a megfelelő betegorvos kapcsolat kialakítása, a beteg tájékoztatása - beleértve azt is, hogy milyen hosszan kell az OAK-terápiát folytatnia -, milyen előnnyel jár a terápia, illetve ennek elhagyása esetén milyen súlyos következményekkel kell a betegnek számolnia. Segíthetnek még a beteg számára érthető edukációs anyagok, illetve a megfelelő intervallumban betervezett gondozás is $[17,18]$.

\section{Limitációk}

- Vizsgálatunkban a NEAK gyógyszerkiváltási adatbázisának retrospektív analízisét végeztük. Ebben nem tudtuk vizsgálni a primer nonadherenciát, amely befolyásolja a teljes adherenciát, ugyanakkor vizsgálatunk nem irányult a primer nonadherencia felmérésére, mivel azt vizsgáltuk, hogy a betegek a felírt (és legalább egyszer kiváltott) gyógyszereket az eloórt adagban és gyakorisággal váltották-e ki.

- A perzisztenciaadatokat nem tudtuk a vizsgálatba belépés - első vénykiváltás - időpontja szerint megbontani, mivel adatbázisunkban csak összesítve volt elérhető az utánkövetési idő (ugyanúgy az egyéves perzisztenciába tartozott az a beteg, aki 2015. június 1-jétôl 2016. május 31-ig volt perzisztens, mint aki 2015. december 31-tól 2016. december 31-ig). A vizsgálati periódus alatt ezért a perzisztenciát esetlegesen befolyásoló tényezőkben történt változásokat nem tudtuk elemezni.
- Vizsgálatunk legfontosabb módszertani limitációja, hogy nem állt rendelkezésünkre adat a potenciális confounderekről, azaz azokról a változókról, amelyek egyszerre befolyásolhatják a gyógyszerrendelést és az adherenciát (például nem, életkor, szociális helyzet, betegségsúlyosság).

- Tekintettel arra, hogy az edoxaban csak 2016. július l-jétől került forgalomba, jelen elemzésünkből kimaradt.

Anyagi támogatás: A szerzők anyagi támogatásban nem részesültek.

Szerzői munkamegosztás: S. G.: A vizsgálat hipotézisének kidolgozása, az adatgyưjtés megtervezése, a kézirat megszövegezése. F. T.: A vizsgálat adatainak statisztikai feldolgozása, az ehhez kapcsolódó módszerek ismertetése, a kézirat szövegezése. M. M., G. R., F. E.: A vizsgálat hipotézisének kidolgozása, a kézirat megszövegezése. A cikk végleges változatát mindegyik szerző elolvasta és jóváhagyta.

Érdekeltségek: A szerzőknek nincsenek érdekeltségeik.

\section{Irodalom}

[1] Benjamin EJ, Virani SS, Callaway CW, et al., on behalf of the American Heart Association Council on Epidemiology and Prevention Statistics Committee and Stroke Statistics Subcommittee. Heart Disease and Stroke Statistics - 2018 Update: A Report from the American Heart Association. Circulation 2018; 137: e67-e492.

[2] Wolf PA, Abbott RD, Kannel WB. Atrial fibrillation: a major contributor to stroke in the elderly. The Framingham Study. Arch Intern Med. 1987; 147: 1561-1564.

[3] Lip GY, Tean KN, Dunn FG. Treatment of atrial fibrillation in a district general hospital. Br Heart J. 1994; 71: 92-95.

[4] Tomcsányi J, Bózsik B, Rokszin Gy, et al. The prevalence of atrial fibrillation in Hungary. [A pitvarfibrilláció prevalenciája Magyarországon.] Orv Hetil 2012; 153: 339-342. [Hungarian]

[5] Kirchhof P, Benussi S, Kotecha D, et al. 2016 ESC Guidelines for the management of atrial fibrillation developed in collaboration with EACTS. Eur Heart J. 2016; 37: 2893-2962.

[6] Platt AB, Localio AR, Brensinger CM, et al. Risk factors for nonadherence to warfarin: results from the IN-RANGE study. Pharmacoepidemiol Drug Saf. 2008; 17: 853-860.

[7] Shore S, Carey EP, Turakhia MP, et al. Adherence to dabigatran therapy and longitudinal patient outcomes: insights from the Veterans Health Administration. Am Heart J. 2014; 167: 810817.

[8] Singer JD, Willett JB. Applied longitudinal data analysis: Modeling change and event occurrence. Oxford University Press, New York, 2003.

[9] Mills M. Introducing survival and event history analysis. Sage Publications, London, 2011.

[10] Willett JB, Singer JD. Investigating onset, cessation, relapse, and recovery: why you should, and how you can, use discrete-time survival analysis to examine event occurrence. J Consult Clin Psychol. 1993; 61: 952-965.

[11] Vrijens B, Urquhart J, White D. Electronically monitored dosing histories can be used to develop a medication-taking habit and manage patient adherence. Expert Rev Clin Pharmacol. 2014; 7 : 633-644. 
[12] Simonyi G, Molnár MP. Persistence of vitamin K antagonist therapy in the real world. Eur Heart J. 2014; 35(Abstract Suppl): 726-727.

[13] Caro JJ, Salas M, Speckman JL, et al. Persistence with treatment for hypertension in actual practice. CMAJ 1999; 160: 31-37.

[14] Raparelli V, Proietti M, Cangemi R, et al. Adherence to oral anticoagulant therapy in patients with atrial fibrillation. Focus on non-vitamin $\mathrm{K}$ antagonist oral anticoagulants. Thromb Haemost. 2017; 117: 209-218.

[15] Bereczky Z, Oláh Z, Ajzner É, et al. Laboratory aspects of novel oral anticoagulant treatment. [Az új orális antikoagulánsokkal történő kezelés laboratóriumi vonatkozásai.] Orv Hetil. 2017; 158: 1930-1945. [Hungarian]
[16] Beyer-Westendorf J, Ehlken B, Evers T. Real-world persistence and adherence to oral anticoagulation for stroke risk reduction in patients with atrial fibrillation. Europace 2016; 18: 1150-1157.

[17] Baroletti S, Dell'Orfano H. Medication adherence in cardiovascular disease. Circulation 2010; 121: 1455-1458.

[18] Szegedi A, Csanádi Z. The efficacy and safety of edoxaban in non-valvular atrial fibrillation. [Az edoxabán véralvadásgátló hatásossága és biztonságossága nonvalvuláris pitvarfibrillációban.] Orv Hetil. 2018; 159: 466-469. [Hungarian]

(Simonyi Gábor dr., Budapest, Tétényi út 12-16., 1115 e-mail: bmbel3@gmail.com)

Budapest Főváros XXIII.kerület Soroksár Önkormányzat

Dr. Nádor Ödön Egészségügyi Intézménye

Intézményvezetö: Dr. Csima Alfréd

1238 Budapest Táncsics M. u. 104.

\section{A Dr. Nádor Ödön Egészségügyi Intézmény \\ tüdőgyógyász szakorvost \\ keres heti 2 óra rendelési időre személyes közremüködőszerződéssel}

A munkavégzés helye: Budapest, 1238 Soroksár, Táncsics M. u. 104.

Feladatok:

- szakorvosi feladatok ellátása szerződés keretében heti 2 óra rendelési időre a jogszabályokban meghatározottaknak és szakmai kompetenciáknak megfelelően, a szakmai protokollok, irányelvek és módszertani útmutatók alapján a felnőtt soroksári lakósók részére.

A szerződés óradijas, számla ellenében történő 15 napos kifizetéssel.

Pályázati feltételek:

- egyetem, általános orvosi diploma, tüdőgyógyászati szakvizsga

- érvényes müködési engedély,

- kamarai tagság,

- büntetlen elöélet,

- egészségügyi alkalmasság.

A pályázat benyújtásának határideje: folyamatos

A pályázathoz csatolandó igazolások:

- szakmai önéletrajz

- iskolai, egyetemi, szakvizsga dokumentumok hiteles másolata

- érvényes működési nyilvántartási igazolás

- MOK tagsági igazolás

A pályázatok benyújtásának módja:

Postai úton, a pályázatnak a Budapest Főváros XXIII. ker. Soroksár Önkormányzatának Dr. Nádor Ödön Egészségügyi Intézménye címére történő megküldésével (1238 Budapest, Soroksár, Táncsics M. u. 104.).

Elektronikus úton Pákáné Csehi Réka vezető asszisztens részére a pakane.csehi.reka@eszi23.hu E-mail címen keresztül

Budapest, 2019. február 25.

Dr. Csima Alfréd

intézményvezető főorvos

A cikk a Creative Commons Attribution-NonCommercial 4.0 International License (https://creativecommons.org/licenses/by-nc/4.0) feltételei szerint publikált Open Access közlemény, melynek szellemében a cikk nem kereskedelmi célból bármilyen médiumban szabadon felhasználható, megosztható és újraközölhető, feltéve, hogy az eredeti szerző és a közlés helye, illetve a CC License linkje és az esetlegesen végrehajtott módosítások feltüntetésre kerülnek. 